\title{
Problema Internal Guru Dalam Penyusunan Silabus Dan RPS Pembelajaran Muatan Lokal Bahasa Daerah Bugis Se-Kecamatan Dua Pitue Sidrap, Sulawesi Selatan, Indonesia
}

\author{
${ }^{1}$ Firman Saleh, ${ }^{2}$ I.Ibrahim, ${ }^{3}$ Muhaiminah Akib \\ ${ }^{1}$ Fakultas Ilmu Budaya,Universitas Hasanuddin \\ ${ }^{2}$ Fakultas Keguruan dan Ilmu Pendidikan, Universitas Muhammadiyah Sorong \\ ${ }^{3}$ Fakultas Keguruan dan Ilmu Pendidikan, Universitas Muhammadiyah Sorong \\ Email:firemansaleh@yahoo.com, iibrahim080988@gmail.com,mina.akib@gmail.com
}

\begin{abstract}
Abstrak
Bahasa daerah sebagai salah satu mata pelajaran yang diajarkan di sekolah khususnya di lingkup wilayah penutur bahasa Bugis. Guru dalam pembelajaran menjadi ujung tombak dalam pencapaian tujuan pembelajaran di kelas. Guru memberikan pencerahan dan pemahaman atas pelajaran yang dibawakan di kelas, selain itu juga menjadi fasilitator dalam pendalaman materi yang diajarkan. Hampir semua komponen terdapat dalam silabus dan dinilai memiliki kelayakan untuk digunakan sebagai panduan guru dalam menyuguhkan materi dalam proses pembelajaran di kelas. Begitu halnya dengan rencana pelaksanaan pembelajaran sangat layak untuk digunakan sebagai pedoman atau landasan dalam mengajarkan pembelajaran bahasa daerah di kelas. Seluruh komponen dalam rencana pelaksanaan pembelajaran disajikan lengkap dan terstruktur sesuai dengan langkah-langkah mulai dari awal pembelajaran hingga guru menutup atau mengakhiri mata pelajaran tersebut.
\end{abstract}

Kata Kunci: Problema Internal, Guru, Silabus dan RPS, Bahasa Daerah Bugis

\section{PENDAHULUAN}

Bahasa daerah merupakan salah satu wujud dari keanekaragaman budaya yang dimiliki oleh bangsa di Indonesia. Bahasa daerah juga merupakan kekayaan budaya lokal dan menjadisebuah identitas yang mewakili setiap etnik. Selain sebagai lambang dan identitas suatu daerah, bahasa daerah juga berfungsi sebagai alat komunikasi yang digunakan dalam lingkungan keluarga dan masyarakat. Apabila bahasa Indonesia berfungsi sebagai alat pemersatu bangsa dan negara, maka bahasa daerah berfungsi sebagai alat pemersatu suku di suatu daerah. Pelestariannya merupakan salah satu upaya mempertahankan jati diri budaya daerah serta jati diri budaya nasional Indonesia. Bahasa merupakan sebuah sistem lambang bunyi yang arbitrer yang dipergunakan oleh para pemakainya untuk bekerja sama, berkomunikasi dan mengidentifikasikan diri (Kridalaksana, 1982:7).

Bahasa daerah sebagai salah satu mata pelajaran yang diajarkan di sekolah khususnya di lingkup wilayah penutur bahasa Bugis, yang merupakan mata pelajaran yang tergolong susah atau rumit bagi siswa. Hal tersebut kemungkinan disebabkan berbagai faktor, bisa dikarenakan dasar yang lemah dari pemerolehan pembelajaran bahasa daerah di tingkat sekolah dasar, bisa 
juga karena sulitnya mengeja aksara yang merupakan aksara tersendiri masyarakat Bugis, bisa juga disebabkan oleh cara mengajar guru yang menakutkan dan membosankan, ataukah minat siswa itu sendiri dalam memeroleh pembelajaran pada mata pelajaran bahasa daerah sebagai muatan lokal di sekolah.

Guru dalam pembelajaran menjadi ujung tombak dalam pencapaian tujuan pembelajaran di kelas. Guru memberikan pencerahan dan pemahaman atas pelajaran yang dibawakan di kelas, selain itu juga menjadi fasilitator dalam pendalaman materi yang diajarkan. Dalam pembelajaran bahasa daerah, guru sangat memiliki peran penting dalam keberhasilan pembelajaran di kelas.Hal tersebut disebabkan karena guru diharapkan memiliki inovasi dan kreativitas dalam pembelaran.

Berdasarkan hasil observasi di sekolah, guru yang mengajarkan mata pelajaran muatan lokal bahasa daerah bugis di SMP Negeri 3 Kalosi Kecamatan Dua Pitue Kabupaten Sidrap bukan guru berasal dari pendidikan bahasa daerah Bugis, melainkan dari lulusan pendidikan bahasa inggris dan matematika. Harapan dalam terciptanya proses belajar mengajar yang kondusif, menarik dan memiliki pembaharuan dalam pembelajaran dengan tujuan untuk menumbuhkan minat dan ketertarikan siswa dalam mengikuti pelaran sangat jauh dari harapan tersebut karena kenyataannya guru yang mengajarkan pelajaran bahasa daerah menggunakan metode yang monoton dan banyak mendapatkan masalah dalam penyusunan perangkat pembelajaran.

Banyak ahli yang mengemukakan bahwa pembelajaran merupakan implementasi kurikulum, tetapi banyak juga yang mengemukakan bahwa pembelajaran itu sendiri merupakan kurikulum sebagai kegiatan. Secara etimologi, kurikulum berasal dari bahasa latin, yaitu "Currere" 'berlari cepat, maju dengan cepat, menjelajahi, merambat, mengelilingi lapangan, gelanggang perlombaan dan sejenisnya'. Jadi curriculum diartikan 'Jarak' yang harus 'ditempuh' oleh pelari (Oemar, $1994: 75)$.

Istilah problema/problematika berasal dari bahasa Inggris yaitu "problematic" yang artinya persoalan atau masalah.Sedangkan dalam bahasa Indonesia, problema berarti hal yang belum dapat dipecahkan; yang menimbulkan permasalahan. (Debdikbud, 2002 :276).

Problema/problematikaadalah suatu kesenjangan antara harapan dan kenyataan yang diharapkan dapat menyelesaikan atau dapat diperlukan atau dengan kata lain dapat mengurangi kesenjangan itu" (Syukir, $1983: 65)$. 
Disimpulkan bahwa problema adalah berbagai persoalan-persoalan sulit yang dihadapi dalam proses pemberdayaan, baik yang datang dari individu tuan guru (faktor eksternal) maupun dalam upaya pemberdayaan masyarakat Islami secara langsung dalam masyarakat. Adapun persoalan-persoalan yang di hadapi dalam proses pembelajaran antara lain dapat berupa: perangkat pembelajaran, kurikulum pembelajaran, motivasi siswa dan bahan ajar.

Peranan kurikulum pada dasarnya sebagai bagian dari penunjangberlangsungnya pembelajaran dalam dunia pendidikan. Hal ini sangatrelevan sekali dengan realita yang ada pada lembaga pendidikan formal karena hampir semua komponen yang ada di lingkungan sekolah tidak lepas denganperencanaan, pelaksanaan, dan penilaian yang semuanya itu merupakan intidari kurikulum. Selanjutnya, Oemar Hamalik mengatakan dalam bukunyayang berjudul Dasar-Dasar Pengembangan Kurikulum setidaknya adaperanan kurikulum yang sangat penting, yakni Peranan konservatif,peranan kritis, atau evaluatif, dan peranan kreatif. Ketiga peranan ini sangatpenting dan perlu dilaksanakan secara seimbang untuk mencapai tujuan (Oemar, 1994 : $30)$.

Keberhasilan seorang guru dalam pembelajaran sangatlah diharapkan. Untuk memenuhi tujuan tersebut diperlukan suatu persiapan yang matang.Sebelum guru mengajar (tahap persiapan) seorang guru diharapkan mempersiapkan bahan yang mau diajarkan, mempersiapkan alat-alat peraga/parktikum yang akan digunakan, mempersiapkan pertanyaan dan arahan untuk memancing siswa aktif belajar, mempelajari keadaan siswa, mengerti kelemahan dan kelebihan siswa, serta mempelajari pengetahuan awal siswa.Kesemuanya ini akan terurai pelaksanaannya di dalam perangkat pembelajaran (Suparno,2002:76).

\section{METODE}

Penelitian ini dilakukan di Kecamatan Dua Pitue Sidrap, Sulawesi Selatan. Data dikumpulkan dengan cara observasi dan wawancara,dokumentasi serta triangulasi. Sample penelitian ini adalah keseluruhan guru Bahasa Daerah pada sekolah yang ada di kecamatan Dua Pitue Sidrap, Sulawesi Selatan. Diata dianalisi dengan munggunakan teknik deskripsi sederhana. 


\section{HASIL DAN PEMBAHASAN}

\section{Silabus dan RPP}

Berdasarkan hasil pengamatan dan uji kelayakan perangkat pembelajaran yang merupakan salah satu komponen yakni silabus yang menjadi pedoman dasar dalam membuat perangkat pembelajaran yang lain yakni rencana pelaksanaan pembelajaran sebagai landasan guru dalam pelaksanaan proses belajar mengajar di kelas pada setiap masing-masing tingkatan kelas VII, kelas VIII dan kelas IX di SMP Negeri di Kecamatan Duapitue dapat diuraikan sebagai berikut ini

a) Standar Kompetensi (SK).

Sesuai dengan standar kompetensi yang harus dicapai oleh siswa kelas VII, kelas VII dan kelas IX di SMP Negeri di Kecamatan Duapitue menjadi kemampuan dasar yang harus dimiliki oleh siswa dalam mata pelajaran muatan lokal Bahasa Daerah Bugis. Gunanya untuk memandu guru dalam menjabarkan kompetensi dasar menjadi pengalaman belajar sehingga rangkaian pembelajaran tidak menyimpang dari koridor kemampuan siswa yang ingin dicapai. Semua silabus dari tiga tingkatan kelas mulai kelas VII, kelas VIII, maupun kelas IX layak untuk digunakan sebagai dasar yang menjadi pedoman guru pada setiap standar kompetensi yang terdapat pada silabus.

b) Kompetensi Dasar (KD).

Pada silabus masing-masing tingkatan kelas VII, kelas VII dan kelas IX di SMP Negeri di Kecamatan Duapitue memiliki kompetensi dasar yang didalamnya menerangkan kemampuan minimal dalam mata pelajaran bahasa daerah yang harus dimiliki dan dapat di tampilkan atau dilakukan oleh siswa. Penempatan KD dalam silabus bertujuan meningkatkan upaya para guru dalam seberapa jauh tuntutan target kompetensi yang harus di capai. Dalam KD juga dimuat hasil belajar, yaitu pernyataan untuk tujuan belajar yang di harapkan setelah peserta didik mengalami pembelajaran dalam kompetensi pembelajaran tertentu. Hal tersebut terpenuhi dalam silabus pelajaran bahasa daerah bugis yang diajarkan masing-masing di kelas VII, kelas VII dan kelas IX di SMP Negeri di Kecamatan Duapitue sehingga layak sesuai dengan kompetensi dasar dalam silabusnya. Setiap KD yang disajikan dalam silabus di masing-masing tingkatan menyuguhkan rentetan kompetensi dasar yang hendak dicapai dalam pembelajaran. 
c) Indikator.

Pada indicator dalam silabus yang terdapat di kelas VII, kelas VII dan kelas IX di SMP Negeri 3 Kalosi Duapituememiliki karakteristik yang sangat menonjolkan bahasa dan budaya lokal sidrap, ciri-ciri yang ditampilkan memberi kesan sebuah kekhasan yang sangat kental dengan budaya lokal, tanda-tanda yang menjadi tujuan pembelajaran di setiap pertemuan dalam pembelajaran bahasa daerah di kelas, perbuatan atau respon yang harus dapat dilakukan atau ditampilkan siswa dalam mengikuti pembelajaran, serta untuk menunjukan bahwa siswa itu telah memiliki kompetensi dasar yang telah dijelaskan di setiap kompetensi dasar yang akan dicapai. Indikator juga merupakan KD yang lebih diuraikan secara spesifik, serangkaian indikator dalam suatu KD sudah dapat di capai siswa, berarti target KD tersebut sudah terpenuhi. Sehingga indicator dalam silabus pada masing masing tingkatan di kelas VII, kelas VII dan kelas IX di SMP Negeri di Kecamatan Duapitue dinyatakan layak untuk digunakan sebagai pedoman dalam pencapaian tujuan pembelajaran.

d) Materi Pokok.

Pada setiap tataran tingkatan di kelas VII, kelas VII dan kelas IX di SMP Negeri 3 Kalosi Duapituedi setiap bagian dari struktur keilmuan suatu bahan kajian yang dapat berupa pengertian konseptual, gugus isi atau konteks, proses, bidang ajar dan keterampilan dalam silabus pembelajaran bahasa daerah Bugis. Setiap pertemuan dipaparkan materi yang diajarkan sesuai dengan indikator pada setiap pencapaian tujuan pembelajaran. Materi pokok di utarakan dalam silabus pada kelas VII, kelas VII dan kelas IX di SMP Negeri 3 Kalosi Duapitue, sehingga layak untuk dijadikan pedoman dalam pembelajaran bahasa daerah di sekolah itu.

e) Pengalaman Belajar.

Di setiap silabus pada masing-masing tingkatan kelas VII, kelas VII dan kelas IX di SMP Negeri 3 Kalosi Duapituememuat rangkaian kegiatan yang harus dilakukan oleh siswa secara berurutan untuk mencapai kompetensi dasar. Pengalaman belajar yang akan dilakukan peserta didik dalam silabus diistilahkan dalam kegiatan pembelajaran siswa yang dilakukan di kelas, sehingga dijelaskan satu per satu kegiatan yang akan dilakukan siswa untuk pencapaian kompetensi dasar. Kegiatan pembelajaran diuraikan sebagai pedoman guru untuk mengajarkan materi secara runut tanpa adanya kerancuan sehingga tujuan pembelajaran yang terdapat dalam silabus tercapai dalam proses belajar mengajar di kelas setiap pertemuan. 
Pengalaman belajar yang terdapat dalam silabus layak untuk digunakan sebagai pedoman guru dalam pembelajaran.

f) Alokasi Waktu.

Dalam pembagian alokasi waktu yang terdapat pada masing-masing silabus yang disusun di kelas VII, kelas VII dan kelas IX di SMP Negeri 3 Kalosi Duapituedengan tujuan untuk merencanakan pembelajaran, lamanya waktu yang diperlukan untuk menguasai KD yang ingin di capai perlu ditentukan alokasi waktunya. Penentuan alokasi waktu yang disesuaikan dengan jumlah minggu efektif dengan mempertimbangkan jumlah, keluasan dan kedalaman KD serta tingkat kepentingan dengan keadaan dan kebutuhan guru dan pencapaian siswa dalam setiap KD pada pembelajaran bahasa daerah. Alokasi waktu pada masing-masing silabus di kelas VII, kelas VII dan kelas IX di SMP Negeri di Kecamatan Duapitue tertata rapi di setiap pertemuan, sehingga dapat dikategorikan dalam alokasi waktu yang layak dipedomani dalam pembelajaran.

g) Sumber / Bahan / Alat.

Sumber belajar yang ideal bagi guru adalah buku, brosur, majalah, surat kabar, poster, lembar informasi lepas, naskah brosur, peta, foto dan lingkungan sekitar. Bahan yang dimaksud adalah bahan-bahan yang di perlukan dalam praktikum atau dalam proses pembelajaran, namun sumber tersebut harus sesuai dengan karakteristik mata pelajaran yang diajarkan. Alat bantu belajar yang dijadikan sumber maupun sebagai bahan bertujuan untuk memudahkan terjadinya proses pembelajaran. Dalam silabus yang disusun disetiap tingkatan di kelas VII, kelas VII dan kelas IX di SMP Negeri 3 Kalosi Duapitue, menjadikan buku ajar sebagai satusatunya sumber belajar bagi siswa dalam pembelajaran bahasa daerah di sekolah itu. Tidak ada sumber belajar lain yang digunakan sebagai alat atau bahan dalam pembelajaran bahasa daerah, sehingga tidak ada keragaman sumber yang menjadi khasanah sumber pengetahuan yang berkaitan dengan pembelajaran. Salah satu kendalanya adalah sangat langkanya buku atau sumber belajar yang ditemukan selain buku ajar yang digunakan guru.

h) Penilaian.

Salah satu komponen silabus yakni penilaian yang di dalamnya terdapat serangkaian kegiatan untuk memperoleh, menganalisis dan menafsirkan data tentang proses dan hasil belajar siswa yang dilakukan secara sistematis dan berkesinambungan, sehingga menjadi informasi yang bermakna dalam pengambilan keputusan untuk memberikan nilai yang pantas untuk siswa. 
Penilaian dapat berbentuk tertulis, produk, unjuk kerja, proyek dan porto folio. Silabus yang didalamnya terdapat komponen penilaian di setiap tingkatan pada kelas VII, kelas VII dan kelas IX di SMP Negeri di Kecamatan Duapitue menyajikan teknik, bentuk instrumen, serta contoh instrument pada kolom penilaian dalam silabus di setiap tingkatan. Dalam kolom teknik terdapat beberapa bentuk yang disajikan adalah tes tertulis dan tes unjuk kerja, sedangkan pada kolom bentuk instrumen terdapat bentuk uraian dan uji kerja produk, serta pada kolom contoh instrumen terdapat bentuk contoh penunjuk soal yang disuguhkan kepada siswa dalam pembelajaran. Dengan mengamati komponen penilaian pada silabus setiap tingkatan kelas VII, kelas VII dan kelas IX di SMP Negeri di Kecamatan Duapitue layak menjadi pedoman guru dalam pembelajaran sesuai dengan standar kompetensi dan kompetensi dasar.

i) Skenario pembelajaran.

Skenario pembelajaran menjadi sebuah rencana dalam bentuk langkah-langkah yang akan di lakukan oleh guru dan siswa selama kegiatan berlangsung. Skenario pembelajaran mengacu kepada pendekatan pembelajaran yang direncanakan dalam kegiatan pembelajaran. Skenario pembelajaran yang dibuat meliputi langkah-langkah pembelajaran di dalam kelas ketika proses belajar mengajar berlangsung, tetapi harus dilakukan setelah proses pembelajaran berlangsung khususnya siswa. Namun dalam silabus pada tingkatan kelas VII, kelas VII dan kelas IX di SMP Negeri 3 Kalosi Duapitue, tidak menyertakan skenario pembelajaran dalam silabus dengan pertimbangan telah terdapat pengalaman belajar yang harus diikuti oleh peserta didik di setiap pertemuan dalam pembelajaran. Dengan pertimbangan demikian sehingga skenario pembelajaran tidak dimuat dalam silabus kelas VII, kelas VII dan kelas IX di SMP Negeri 3 Kalosi Duapitue.

j) Analisis hasil belajar dan program tindak lanjut

kegiatan membangdingkan hasil belajar siswa dengan standar ketuntasan belajar minimum (SKBM) yang telah di tetapkan merupakan tujuan dilakukannya analisis hasil belajar dan program tindak lanjut dalam pembelajaran yang dijadikan pedoman dalam silabus. Namun komponen ini tidak tersaji dalam bagian dari komponen silabus yang terdapat dalam pembelajaran bahasa daerah di kelas VII, kelas VII dan kelas IX di SMP Negeri 3 Kalosi Duapitue. 
Berdasarkan uraian dari semua komponen yang terdapat pada silabus masing-masing tingkatan di kelas VII, kelas VII dan kelas IX di SMP Negeri 3 Kalosi Duapitue, merupakan silabus yang layak dijadikan pedoman dalam pembelajaran bahasa daerah di sekolah. Hampir semua komponen terdapat dalam silabus dan dinilai memiliki kelayakan untuk digunakan sebagai panduan guru dalam menyuguhkan materi dalam proses pembelajaran di kelas.

Di balik kelayakan silabus yang digunakan guru di setiap tingkatan kelas VII, kelas VII dan kelas IX di SMP Negeri di Kecamatan Duapitue menuai pengakuan yang secara jujur diungkapkan oleh kedua guru yang mengampuh mata pelajaran bahasa daerah di sekolah itu menyatakan bahwa bukanlah dia yang membuat silabus yang dijadikan pedoman. Silabus tersebut dibuat oleh Tim MGMP mata pelajaran bahasa daerah di Kabupaten Sidrap. Dari pengakuannya juga diungkapkan bahwa semua silabus pembelajaran bahasa daerah ada di sekolah lanjutan tingkat pertama sekabupaten Sidrap semuanya sama.

Guru yang mengajarkan mata pelajaran bahasa daerah di SMP Negeri di Kecamatan Duapitue merasa tidak pernah diundang dalam pertemuan MGMP bahasa daerah di Kabupaten Sidrap, dengan mengingat kedua guru tersebut bukan merupakan lulusan guru bahasa daerah karena hanya merangkap dan menjalankan penugasan dari kepala sekolah. Hal itulah yang membuat kedua guru yang mengajarkan bahasa daerah tidak sepenuhnya memberikan perhatian serta keseriusan dalam menyusun perangkat pembelajaran maupun dalam mengajarkannya, sehingga cara yang dilakukan untuk memiliki silabus guna dijadikan bukti administrasi guru sebagai pengajar dalam mata pelajaran bahasa daerah dengan cara menyalin miliki rekan guru dari sekolah lain.

Salah satu bentuk problematika dalam pembelajaran oleh guru dalam penyusunan perangkat pembelajaran bahasa daerah khususnya pada komponen ini yakni dengan penggunaan silabus yang monoton dan tidak ada inovasi serta evaluasi setiap tahun. Cara gampang yang digunakan guru hingga sekarang ini hanyalah mengganti tahun ajaran pada silabus, karena yang dijadikan dasar dalam pembuatan silabus adalah buku ajar. Hal tersebut yang terjadi hingga saat ini dalam penyusunan silabus masing-masing di kelas VII, kelas VIII dan kelas IX khususnya di SMP Negeri 3 Kalosi Duapitue. 


\section{Rencana Pelaksanaan Pembelajaran (RPP)}

Salah satu perangkat pembelajaran yang harus disusun oleh guru adalah rencana pelaksanaan pembelajaran atau biasa disingkat RPP, merupakan suatu pedoman guru dalam pelaksanaan proses belajar mengajar setiap pertemuan di kelas. Guru diharuskan membuat RPP sebagai sebuah kelengkapan administrasi pada mata pelajaran yang diajarkan untuk sekolah, serta menjadi landasan atau pedoman bagi guru itu sendiri dalam menyuguhkan materi agar terstruktur sesuai dengan tahapan demi tahapan dengan tujuan menghindari kerancuhan penyuguhan materi oleh guru di kelas dalam proses belajar mengajar.

Rencana pelaksanaan pembelajaran di kelas VII, kelas VIII dan kelas IX khususnya di SMP Negeri di Kecamatan Duapitue setiap pertemuan selama semester ganjil telah dibuat dan disusun secara runut oleh guru yang mengajarkan mata pelajaran bahasa daerah. Rencana pelaksanaan pembelajaran dibuat dengan berpedoman pada silabus pelajaran bahasa daerah, dengan tujuan agar rencana pelaksanaan pembelajaran senantiasa terkait dengan silabus yang telah dibuat guna pencapaian tujuan pembelajaran.

Setelah mengamati dan mencermati rencana pelaksanaan pembelajaran yang telah dibuat pada masing-masing kelas VII, kelas VIII dan kelas IX di SMP Negeri di Kecamatan Duapitue di setiap pertemuan, sesuai dengan panduan pembuatan rencana pelaksanaan pembelajaran terdapat komponen-komponen yang harus terdapat rencana pelaksanaan pembelajaran di setiap pertemuan.

Komponen-komponen pada rencana pelaksanaan pembelajaran di setiap tingkatan masing-masing di kelas VII, kelas VIII dan kelas IX di SMP Negeri di Kecamatan Duapitue disusun secara sistematis dan lengkap antara lain:

a) Kolom identitas mata pelajaran, pada bagian ini guru menjabarkan nama sekolah tempat dilaksanakannya pembelajaran bahasa daerah, mata pelajaran yang diajarkan, terdapat pula kelas yang diajarkan dan semester yang akan dijalani, serta tahun ajaran.

b) Standar Kompetensi, pada standar kompetensi yang terdapat pada setiap rencana pelaksanaan pembelajaran di masing-masing tingkatan kelas VII, kelas VIII dan kelas IX di SMP Negeri di Kecamatan Duapitue berdasar pada silabus. Standar kompetensi yang terdapat pada silabus dibuat dalam standar kompetensi pada rencana pelaksanaan pembelajaran sebagai pedoman guru dalam memetakan materi di setiap pertemuan. Standar kompetensi menjadi landasan 
utama guru dalam mengajarkan materi di kelas agar tidak rancuh dan beraturan dari awal hingga akhir semester.

c) Kompetensi dasar, pada rencana pelaksanaan pembelajaran yang dibuat oleh guru pengasuh mata pelajaran bahasa daerah di masing-masing tingkatan di kelas VII, kelas VIII dan kelas IX di SMP Negeri di Kecamatan Duapitue dibuat sesuai kompetensi dasar yang terdapat pada silabus yang menjadi pedoman dan merupakan bagian standar kompetensi pada setiap rencana pelaksanaan pembelajaran.

d) Indikator Pencapaian Kompetensi, begitu pula dengan indikator yang merupakan bagian yang menjadi turunan kompetensi dasar pembelajaran pada setiap rencana pelaksanaan pembelajaran masing-masing kelas VII, kelas VIII dan kelas IX khususnya di SMP Negeri 3 Kalosi Duapitue. Setiap rencana pelaksanaan pembelajaran yang dibuat oleh guru, terdapat indikator pencapaian kompetensi yang dijabarkan dari kompetensi dasar yang menjadi pedoman guru dalam menyajikan materi di kelas.

e) Tujuan Pembelajaran

Dalam standar isi dan standar kompetensi lulusan tujuan pembelajaran dirumuskan dalam bentuk kompetensi yang harus dicapai atau dikuasai oleh siswa. Melalui rumusan tujuan, guru dapat memproyeksikan apa yang harus dicapai oleh siswa setelah berakhir suatu proses pembelajaran. Begitu halnya yang terdapat di setiap rencana pelaksanaan pembelajaran pada masing-masing tingkatan kelas VII, kelas VIII dan kelas IX di SMP Negeri di Kecamatan Duapitue dijelaskan secara detail mengenai tujuan pembelajaran di setiap pertemuan pembelajaran bahasa daerah di kelas.

f) Materi Ajar (Materi Pokok)

Materi pelajaran yang berkaitan dengan bahan pelajaran yang harus dikuasai guru untuk diberikan kepada siswa sesuai dengan tujuan pembelajaran. Materi pelajaran harus digali dari berbagai sumber belajar sesuai dengan kompetensi yang harus dicapai. Hal itu terdapat pada komponen materi ajar yang terdapat pada rencana pelaksanaan pembelajaran pada masingmasing tingkatan di kelas VII, kelas VIII dan kelas IX di SMP Negeri di Kecamatan Duapitue di setiap pertemuan. Kegunaan materi ajar bagi guru pada rencana pelaksanaan pembelajaran sebagai pedoman dalam pembelajaran agar materi ajar tidak bertukar atau disajikan berulang dalam proses belajar mengajar di kelas. 
g) Alokasi Waktu, pada rencana pelaksanaan pembelajaran masing-masing tingkatan kelas VII, kelas VIII dan kelas IX di SMP Negeri di Kecamatan Duapitue yang dibuat oleh guru membagi alokasi waktu yang disesuaikan dengan jumlah jam yang harus diajarkan dalam pembelajaran bahasa daerah. Alokasi waktu yang dituangkan pada rencana pelaksanaan pembelajaran sesuai dengan hasil pembagian waktu dengan materi yang akan diajarkan, telah ditetapkan waktu yang akan digunakan dalam menyajikan setiap materi.

h) Metode Pembelajaran

Strategi adalah rancangan serangkaian kegiatan untuk mencapai tujuan tertentu, sedangkan metode adalah cara yang digunakan untuk mengimplementasikan strategi. Dengan demikian strategi dan metode itu tidak bisa dipisahkan. Strategi dan metode pembelajaran harus dirancang sesuai dengan tujuan yang ingin dicapai. Metode yang digunakan guru dalam menyajikan pelajaran kepada siswa di kelas semuanya dijelaskan pada rencana pelaksanaan pembelajaran di bagian komponen metode pembelajaran. Metode pembelajaran yang dipilih selalu dikawinkan dengan model pembelajaran yang sesuai, dengan tujuan agar penyajian materi lebih menarik bagi siswa dalam pembelajaran di kelas.

i) Kegiatan Pembelajaran, pada rencana pelaksanaan pembelajaran yang dituangkan guru pada komponen kegiatan pembelajaran di masing-masing tingkatan kelas VII, kelas VIII dan kelas IX khususnya di SMP Negeri di Kecamatan Duapitue menyuguhkan kegiatan mulai dari kegiatan awal kemudian kegiatan inti hingga kegiatan akhir, sehingga pada komponen ini tersusun secara struktur dan sesuai dengan tahapan demi tahapan dari awal dimulainya pembelajan di kelas hingga guru menutup pembelajaran yang merupakan kegiatan akhir dalam kegiatan pembelajaran.

j) Penilaian, pada rencana pelaksanaan pembelajaran yang dibuat untuk masing-masing tingkatan kelas VII, kelas VIII dan kelas IX di SMP Negeri 3 Kalosi Duapitue, evaluasi diarahkan bukan hanya sekedar untuk mengukur keberhasilan setiap siswa dalm pencapaian hasil belajar, tetapi juga untuk mengumpulkan informasi tentang proses pembelajaran yang dilakukan setiap siswa. Oleh sebab itu, dalam perencanaan pelaksanaan pembelajaran setiap guru tidak hanya menentukan tes sebagai alat evaluasi akan tetapi juga menggunakan nontes dalam bentuk tugas, wawancara, dan lain sebagainya.Pada rencana pelaksanaan pembelajaran yang dibuat guru menyajikan teknik penilaian, bentuk penilaian, serta instrumen penilaian sehingga jelas dalam proses penilaian. 
k) Sumber Belajar, pada rencana pelaksanaan pembelajaran yang dibuat guru untuk masingmasing tingkatan kelas VII, kelas VIII dan kelas IX di SMP Negeri di Kecamatan Duapitue menjadikan buku sebagai media dalam proses pembelajaran dapat diartikan sebagai alat bantu untuk mempermudah pencapaian tujuan pembelajaran. Rencana pelaksanaan pembelajaran yang dibuat oleh guru hanya menjadikan sebuah buku sebagai sumber belajar tanpa ada sumber belajar lain yang menjadi sumber belajar penunjang untuk pembelajaran bahasa daerah.

Berdasarkan keseluruhan komponen yang terdapat pada rencana pelaksanaan pembelajaran yang dibuat oleh guru yang mengampuh mata pelajaran di masing-masing tingkatan kelas VII, kelas VIII dan kelas IX di SMP Negeri di Kecamatan Duapitue sangat layak untuk digunakan sebagai pedoman atau landasan dalam mengajarkan pembelajaran bahasa daerah di kelas. Seluruh komponen dalam rencana pelaksanaan pembelajaran disajikan lengkap dan terstruktur sesuai dengan langkah-langkah mulai dari awal pembelajaran hingga guru menutup atau mengakhiri mata pelajaran tersebut.

Hasil dari analisis data yang berupa rencana pelaksanaan pembelajaran yang dimiliki oleh guru yang mengajarkan mata pelajaran bahasa daerah pada masing-masing tingkatan di kelas VII, kelas VIII dan kelas IX di SMP Negeri di Kecamatan Duapitue memang memenuhi kriteria rencana pelaksanaan pembelajaran yang ideal dan layak untuk dijadikan pegangan dalam penyajian materi di kelas. Namun terdapat kontropersi dalam pengakuan guru yang mengajarkan mata pelajaran bahasa daerah di sekolah ini saat interview atau wawancara, bahwa rencana pelaksanaan pembelajaran dibuat hanya satu kali saja dan itulah yang digunakan terus-menerus sampai sekarang.

Rencana pelaksanaan pembelajaran tersebut hanya diganti tahunnya pada setiap pergantian tahun ajaran, dalam artian bahwa tidak ada pembaruan dan inovasi yang dilakukan guru dalam membuat rencana pelaksanaan pembelajaran khususnya mata pelajaran bahasa daerah. Kesan dari rencana pelaksanaan pembelajaran tersebut monoton dan tidak ada kretifitas yang diciptakan oleh guru yang mengamput mata pelajaran bahasa daerah di sekolah SMP Negeri di Kecamatan Duapitue Kabupaten Sidrap.

Bagi guru yang mengampuh mata kuliah bahasa daerah diharapkan mampu menyusun perangkat pembelajaran sendiri tanpa menyalin dari orang lain. Bagi kepala sekolah, diharapkan tidak asal menunjuk guru yang mengajarkan mata pelajaran bahasa daerah. Seharusnya 
menugaskan guru yang lulusan pendidikan bahasa daerah, apabila tidak memiliki guru lulusan pendidikan bahasa daerah, baiknya menugaskan guru yang berkompetensi dalam pengajaran bahasa dan mampu berbicara serta membaca dan memaknai kosakata dari aksara lontara. Bagi peneliti selanjutnya, diharapkan mampu melanjutkan penelitian dengan mengungkapkan sudut pandang yang berbeda dengan objek yang sama. Dengan tujuan menambah khasanah pengetahuan tentang problematika guru atau perangkat pembelajaran yang digunakan guru di kelas sebagai pedoman atau panduan dalam menjalankan proses belajar mengajar di kelas.

Faktor-faktor yang memengaruhi timbulnya masalah atau problematika guru dalam penyusunan perangkat pembelajaran, salah satunya adalah guru yang mengajarkan mata pelajaran muatan lokal bahasa daerah bukan lulusan pendidikan bahasa daerah. Guru tersebut ditunjuk langsung dan ditugaskan oleh kepala sekolah untuk mengajarkan mata pelajaran muatan lokal bahasa daerah. tidak terlalu berminat dan merasa terpaksa dalam mengajarkan mata pelajaran bahasa daerah ini.

\section{SIMPULAN}

Hasil penelitian yang dilaksanakan di SMP Negeri di Kecamatan Duapitue Kabupaten Sidrap menunjukkan bahwa berdasarkan uraian dari semua komponen yang terdapat pada silabus masing-masing tingkatan di kelas VII, kelas VII dan kelas IX di SMP Negeri di KecamatanDuapitue, merupakan silabus yang layak dijadikan pedoman dalam pembelajaran bahasa daerah di sekolah. Hampir semua komponen terdapat dalam silabus dan dinilai memiliki kelayakan untuk digunakan sebagai panduan guru dalam menyuguhkan materi dalam proses pembelajaran di kelas. Begitu halnya dengan rencana pelaksanaan pembelajaran sangat layak untuk digunakan sebagai pedoman atau landasan dalam mengajarkan pembelajaran bahasa daerah di kelas. Seluruh komponen dalam rencana pelaksanaan pembelajaran disajikan lengkap dan terstruktur sesuai dengan langkah-langkah mulai dari awal pembelajaran hingga guru menutup atau mengakhiri mata pelajaran tersebut. 


\section{DAFTAR PUSTAKA}

Chaer, Abdul. 1995. Bahasa: Suatu Pengantar. Jakarta: Rineke Cipta.

Darsono. 2001. Belajar dan Pembelajaran. Semarang : IKIP Semarang Press.

Debdikbud 2002. Kamus Besar Bahasa Indonesia hal 276. Jakarta: Bulan Bintang.

Depdiknas. 2008(a). Panduan Pengembangan Bahan Ajar. Jakarta: Direktorat Pembinaan SMA, Dirjen Mandikdasmen, Depdiknas.

Direktorat Pembinaan Sekolah Menengah Pertama. 2009. Buku Saku Kurikulum Tingkat Satuan Pendidikan (KTSP) Sekolah Menengah Pertama. Jakarta: Departemen Pendidikan Nasional, Direktorat Jendral Manajemen Pendidikan Dasar dan Menengah.

Gafur, Abdul, 1986. Langkah Sistematis Penyusunan Pola Dasar Kegiatan Belajar Mengajar. Sala: Tiga Serangkai.

Hudoyo, H. 1988. Mengajar Belajar Matematika. Jakarta: Dirjen Dikti Depdiknas.

Khaeruddin, dkk, Kurikulum Tingkat Satuan Pendidikan (KTSP), Jogjakarta: Nuansa Aksara,Cet II, 2007.

Larasati, Dkk. 1998. "Inovasi Pendidikan: Model Strategi Pelaksanaan Kurikulum Muatan Lokal Pendidikan Dasar di Wilayah Pantai Utara Jawa Tengah". Laporan Penelitian diterbitkan. Semarang: Fakultas Ilmu Sosial dan Ilmu Politik, Universitas Diponegoro.

Majid, Abdul. 2007. Perencanaan Pembelajaran. Bandung : PT. Remaja Rosdakarya.

Mbete, Aron Meko. 2006. “ Strategi Pemberdayaan Bahasa Daerah, Bahasa Indonesia, dan Bahasa Asing sebagai Sumber Daya Kebudayaan”. Makalah yang disajikan dalam "Seminar Nasional Bahasa Dawan". Diselenggarakan oleh PS Pendidikan bahasa dan sastra Indonesia FKIP Universitas PGRI, So’E, NTT Tanggal 18 September 2006.

Moeliono.1981. Pengembangan dan Pembinaan Bahasa. Jakarta: Jambatan.

Moleong. 2000. Metodologi Penelitian Kualitatif. Bandung: Remaja Rosda Karya.

Mulyana. 2008. Pembelajaran Bahasa dan Sastra Daerah Dalam Kerangka Budaya. Jokjakarta: Tiara Wacana.

Mulyasa.2007. Kurikulum Tingkat Satuan Pendidikan : Sebuah Panduan Praktis; Bandung: Remaja Rosda.

Muslich. 2007. “KTSP(Kurikulum Tingkat Satuan Pendidikan) Dasar Pemahaman dan Pengembangan”. Jakarta: Bumi Aksara.

Oemar Hamalik. 1994. Kurikulum dan Pembelajaran. Jakarta : PT Bumi Aksara

Purwo, Bambang Kaswanti. 2003. "Pengajaran Bahasa Nusantara di Indonesia”. Jakarta: Makalah Seminar Hari Bahasa Ibu Internasional

Reigeluth, Charles. 1987. Instructional Theories in action: Lessons Illustrating Selected Theories and Models. New Jersey: Lawrence Erlbaum Associates Publ.

Rosidi. 1999. Bahasa Nusantara: Satuan Pemetaan awal. Gambaran tentang Bahasa-bahasa Daerah di Indonesia. Jakarta: Dunia Pustaka Jaya.

Rusman.2009. Manajemen Kurikulum. Jakarta: Rajawali Pers Divisi Buku Perguruan Tinggi PT Raja Grafindo Persada.

Sanjaya, Wina, Perencanaan dan Desain Sistem Pembelajaran, Jakarta: Kencana, 2010.

Sayuti, Sumianto A. 2003. “Muatan lokal dalam penyelenggaraan Pendidikan”. Bukittinggi: Makalah Kongres Kebudayaan. 
Sugiyono.2010. Metode Penelitian Pendidikan, Pendekatan Kuantitatif, Kualitatif dan $R \&$ D. Bandung : Alfabeta.

Sukardi. 2003. Metodologi Penelitian Pendidikan. Jakarta : PT. Bumi Aksara.

Sulistyowati, E. 2009. Bahan Ajar, (Online), (endahsulistyowati.wordpress.com /apakahperbedaan-bahan-ajar-dan-sumber-belajar/, diakses 21 Maret 2010).

Sumardi. 1996. Berbagi Pendekatan Dalam Pengajaraan Bahasa dan Sastra. Jakarta: Pustaka Sinar Haraoan.

Sunaryo, dkk, Kurikulum Tingkat Satuan Pendidikan (KTSP), Jakarta: LAPIS. Tht.

Suparno,P. 2001. Teori Perkembangan Kognitif Jean Piaget. Yogyakarta: Kanisus.

Susilo, Muhammad Joko, KTSP, Yogyakarta: Pustaka Pelajar, 2008. 